
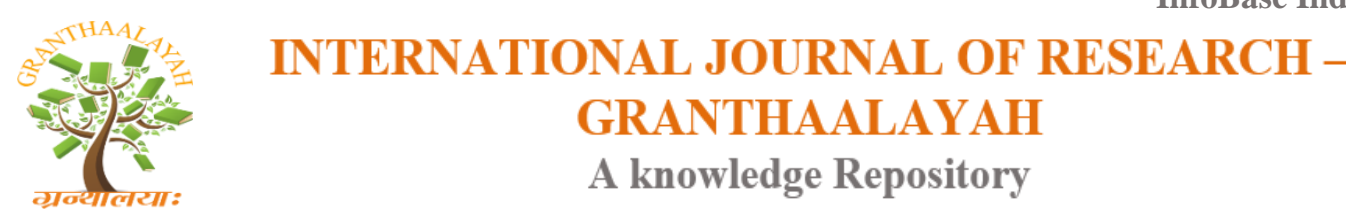

Management

\title{
SOLAR POWER THE SUPER POWER
}

\author{
D.P.Jesudoss Manohar ${ }^{* 1}$, T.Jayaprakasam ${ }^{2}$ \\ *1 Assistant Professor, Nehru Memorial College, India \\ ${ }^{2}$ Principal, Nehru Memorial College, India
}

DOI: https://doi.org/10.29121/granthaalayah.v5.i1(SE).2017.1922

\begin{abstract}
India is facing an acute energy scarcity which is hampering its industrial growth and economic progress. Setting up of new power plants is inevitably dependent on import of highly volatile fossil fuels. Thus, it is essential to tackle the energy crisis through judicious utilization of abundant the renewable energy resources, such as Biomass Energy solar Energy, Wind Energy and Geothermal Energy. Apart from augmenting the energy supply, renewable resources will help India in mitigating climate change. India is heavily dependent on fossil fuels for its energy needs. Most of the power generation is carried out by coal and mineral oil-based power plants which contribute heavily to greenhouse gases emission. Solar Power a clean renewable resource with zero emission, has got tremendous potential of energy which can be harnessed using a variety of devices.
\end{abstract}

Keywords: Solar Energy; Emission; Industrial Growth \& Power.

Cite This Article: D.P.Jesudoss Manohar, and T.Jayaprakasam. (2017). "SOLAR POWER THE SUPER POWER." International Journal of Research - Granthaalayah, 5(1)SE, 58-61. https://doi.org/10.29121/granthaalayah.v5.i1(SE).2017.1922.

\section{Introduction}

Solar Energy a clean renewable resource with Zero emission, has got tremendous potential of energy which can be harnessed using a variety of devices. With recent developments, solar energy systems are easily available for industrial and domestic use with the added advantage of minimum maintenance. Solar energy could be made financially viable with government tax incentives and rebates. Most of the developed countries are switching over to solar energy as one of the prime renewable energy source. The current architectural designs make provision for photovoltaic cells and necessary circuitry while making building plans. The National Solar Mission is a major initiative of the Government of India and State Governments to promote ecologically sustainable growth while addressing India's energy security challenge. It will also constitute a major contribution by India to the global effort to meet the challenges of climate change. The objective of the National Solar Mission is to establish India as a global leader in 
solar energy, by creating the policy conditions for its diffusion across the country as quickly as possible. The immediate aim of the Mission is to focus on setting up an enabling environment for solar technology penetration in the country both at a centralized and decentralized level. The National Action Plan on Climate Change also points out: "India is a tropical country, where sunshine is available for longer hours per day and in great intensity. Solar energy, therefore, has great potential as future energy source. It also has the advantage of permitting the decentralized distribution of energy, thereby empowering people at the grassroots level".

\section{History of the Solar Market in India}

The Rural Electrification Program of 2006 was the first step by the Indian Government in recognizing the importance of solar power. It gave guidelines for the implementation of off-grid solar applications. However, at this early stage, only 33.8MW (as on 14-2-2012) of capacity was installed through this policy. This primarily included solar lanterns, solar pumps, home lighting systems, street lighting systems and solar home systems. In2007, as a next step, India introduced the Semiconductor Policy to encourage the electronic and IT industries.This included the Silicon and PV manufacturing industry as well. New manufacturers like Titan Energy Systems, Indo Solar Limited and KSK Surya Photovoltaic Venture Private Limited took advantage of the Special Incentive Scheme included in this policy and constructed plants for PV modules. This move helped the manufacturing industry to grow, but a majority of the production was still being exported. There were no PV projects being developed in India at that stage. There was also a need for a policy to incorporate solar power into the grid.

\section{Growth of Solar Energy in India}

India's government has begun to acknowledge the importance of solar energy to the country's economic growth. Prime Minister Manmohan Singh, who has said solar energy will transform rural India, launched a National Solar Mission in 2010. Initial growth has been dramatic, albeit from a tiny base. From less than $12 \mathrm{MW}$ in 2009, solar-power generation in the country grew to $190 \mathrm{MW}$ in 2011. By March 2013, it is expected to grow fivefold to 1,000 MW, but the country has a long way to go to reach its goal of increasing solar-power generation to 20 gigawatts by 2020. Across India, there are still thousands of villages with plenty of sun but not enough power.

\section{Jawaharlal Nehru National Solar Mission}

The Jawaharlal Nehru National Solar Mission aims at development and deployment of solar energy technologies in the country to achieve parity with grid power tariff by 2022 . The National Solar Mission is a major initiative of the Government of India and State Governments to promote ecologically sustainable growth while addressing India's energy security challenge. It will also constitute a major contribution by India to the global effort to meet the challenges of climate change. The objective of the National Solar Mission is to establish India as a global leader in solar energy, by creating the policy conditions for its diffusion across the country as quickly as possible. The aim would be to protect Government from subsidy exposure in case expected cost reduction does not materialize or is more rapid than expected. The immediate aim of the Mission is to focus on setting up an enabling environment for solar technology penetration in the country both at a centralized and decentralized level. 
The main features of the National Solar Mission are:

1) Make India a global leader in solar energy and the mission envisages an installed solar generation capacity of 20,000 MW by 2022, 1,00,000 MW by 2030 and of 2,00,000 MW by 2050.

2) The total expected investment required for the 30 -year period will run is from Rs. 85,000 crore to Rs. 105,000 crore.

3) Between 2017 and 2020, the target is to achieve tariff parity with conventional grid power and achieve an installed capacity of 20 gigawatts $(\mathrm{Gw})$ by 2020 .

4) 4-5GW of installed solar manufacturing capacity by 2017.

5) To deploy 20 million solar lighting systems for rural areas by 2022

\section{India's First Solar Park}

On December 29th 2010, India's first solar park was inaugurated at Charanaka in Patan district of northern Gujarat. So far, land has been allotted in the solar park for projects worth $176 \mathrm{MW}$ to 16 companies from the first and second phases. The total capacity of the solar park is 500MW with 30,000 sq. m per MW land allotted to Solar Thermal and 20,000 sq. m per MW of land allotted to PV projects. The solar park has been financed with over Rs. 12 billion by financial institutions like the International Finance Corporation (IFC), the Asian Development Bank (ADB) and the Infrastructure Development Finance Corporation (IDFC). The park tackles land procurement, water availability and grid connectivity issues and offers a "single-window" clearance process.

\section{Solar Thermal Process}

Solar thermal electricity technologies produce electric power by converting the sun's energy into high temperature heat using various mirror configurations, which is then channeled to an on-site power plant and used to make electricity through traditional heat-conversion technologies. The plant essentially consists of two parts; one that collects solar energy and converts it to heat, and another that converts the heat energy to electricity.

\section{Solar Cell}

A solar cell is a semiconductor device that transforms sunlight into electricity. Semiconductor material is placed between two electrodes. When sunshine reaches the cell, free negatively charged electrons are discharged from the material, enabling conversion to electricity. This is the so-called photovoltaic effect. In theory, a solar cell made from one semiconductor material only can convert about 30 percent of the solar radiation energy it is exposed to into electricity. Commercial cells today, depending on technology, typically have an efficiency of 5-12 percent for thin films and $13-21$ percent for crystalline silicon based cells. Efficiencies up to 25 percent have been reached by the use of laboratory processes. By using multiple solar cells, efficiencies above 35 percent have been achieved.

\section{Solar Photovoltaics}


Photovoltaic has been derived from the combination of two words, Photo means Light and Voltaic means electricity. It is a technology that converts light directly into electricity. Photovoltaic material, most commonly utilizing highly-purified silicon, converts sunlight directly into electricity.

\section{Rural Electrification}

Lack of electricity infrastructure is one of the main hurdles in the development of rural India. India's grid system is considerably under-developed, with major sections of its populace still surviving off-grid. As of 2004 there are about 80,000 unelectrified villages in the country. Of these villages, 18,000 could not be electrified through extension of the conventional grid. A target for electrifying 5,000 such villages was fixed for the Tenth National Five Year Plan (2002-2007). As on 2004, more than 2,700 villages and hamlets had been electrified mainly using SPV systems. Developments on cheap solar technology are considered as a potential alternative that allows an electricity infrastructure comprising of a network of local-grid clusters with distributed electricity generation. That could allow bypassing, or at least relieving the need of installing expensive, and lossy, long-distance centralised power delivery systems and yet bring cheap electricity to the masses.3000 villages of Odissa will be lighted with Solar power by 2014. The off-grid and rooftop segments will grow exponentially as price parity with consumer tariffs makes solar power an economically viable alternative, particularly for urban and semi-urban consumers. Distributed International Journal of Environmental Science: Development and Monitoring

\section{Conclusion}

Although India's solar market appears well suited for local players, it's currently open to global players as well. Indeed, global firms that tailor their broad expertise to serve unique local needs in a frugal way could actually extract significant value. At the same time, local players can bridge capability gaps by striking appropriate alliances, or by recruiting strong teams or individuals. A partnership of foreign technology and local EPC can help both parties climb up the steep learning curve fast, but mechanisms will need to be put in place to ensure that the risks and upsides are shared equally.

\section{References}

[1] Arthi, S., Regi, S. B., \& Golden, S. A. R. (2014). Green Marketing - An Overview. Indian Streams Research Journal, 4(2), 1-4.

[2] Charles, R. P., Davis, K. W., \& Smith, J. L. (2005). Assessment of concentrating solar power technology cost and performance forecasts. Sargent \& Lundy LLC, Technical Report.

[3] Jacobson, M. Z., \& Delucchi, M. A. (2011). Providing all global energy with wind, water, and solar power, Part I: Technologies, energy resources, quantities and areas of infrastructure, and materials. Energy policy, 39(3), 1154-1169.

[4] Regi, S. B., Golden, S. A. R., \& Franco, C. E. (2014). ENERGY POVERTY IN INDIA - AN EMPIRICAL STUDY. Tactful Management Research Journal, 2(6), 1-5.

[5] Nakamura, T. (1992). U.S. Patent No. 5,089,055. Washington, DC: U.S. Patent and Trademark Office. 